\title{
Program postępowania terapeutyczno-rehabilitacyjnego wobec pacjentów jąkających się
}

\section{Therapeutic-rehabilitation procedure in cases of stuttering patients}

\author{
Marzena Mularzuk $^{1,2}$, Agata Szkiełkowska ${ }^{1,2}$, Zdzisław Marek Kurkowski ${ }^{1,2}$, \\ Joanna Ratyńska ${ }^{1,2}$ \\ ${ }^{1}$ Instytut Fizjologii i Patologii Słuchu, ul. Zgrupowania AK „Kampinos” 1, 01-943 Warszawa \\ ${ }^{2}$ Światowe Centrum Słuchu, ul. Mokra 17, Kajetany, 05-830 Nadarzyn
}

Adres autora: Instytut Fizjologii i Patologii Słuchu, ul. Zgrupowania AK „Kampinos” 1, 01-943 Warszawa

Streszczenie

Celem pracy jest przedstawienie metodyki postępowania terapeutyczno-rehabilitacyjnego u osób jąkających się, opracowanego przez zespół specjalistów Instytutu Fizjologii i Patologii Słuchu.

\begin{abstract}
Schemat postępowania terapeutyczno-rehabilitacyjnego u osób jąkających się wyszczególnia wszystkie stosowane w IFPS me-
\end{abstract} tody $\mathrm{z}$ uwzględnieniem kolejności i czasu ich zastosowania.

\begin{abstract}
Program zawiera wieloprofilowe elementy terapeutyczne w rehabilitacji logopedycznej, takie jak: ćwiczenia oddechowe, ćwiczenia oddechowo-emisyjne, ćwiczenia motoryki artykulacyjnej, ćwiczenia startu mowy i rytmizacji wypowiedzi, ćwiczenia relaksacyjne oraz ćwiczenia z cyfrowym korektorem mowy (CKM) w schemacie zajęć indywidualnych i grupowych.
\end{abstract}

Opracowany program postępowania zastosowano w grupie pacjentów jąkających się, osiągając pozytywne efekty terapeutyczne. Wyniki badań obiektywnych wskazują, że opracowany i wdrożony program leczniczo-rehabilitacyjny z wyszczególnieniem działań logopedycznych i zastosowaniem cyfrowego korektora mowy (CKM) jest wartościowym narzędziem w terapii osób jąkających się.

słowa kluczowe: jąkanie • cyfrowy korektor mowy • terapia logopedyczna • turnusy rehabilitacyjne

Abstract

The aim of this study is to present methodology of therapeutical and rehabilitation management of stuttering individuals, developed in the Institute of Physiology and Pathology of Hearing.

The procedure of the therapeutical and rehabilitation management of stuttering individuals specifies all methods used in the Institute, taking into consideration their sequence and time of application.

The program includes multifaceted therapeutical elements of speech therapy, such as: breathing exercises, breathing-emission exercises, exercises of articulation movements, exercises for gentle speech onset and fluency shaping, relaxation exercises and exercises with the digital speech corrector in the individual and group therapy programs.

The management program developed in the Institute was applied in a group of stuttering patients with positive therapeutical results. Objective measurements results indicate that this treatment and rehabilitation program, specifying speech therapy management and application of the digital speech corrector, is a valuable tool in the therapy of stuttering patients.

key words: stuttering • digital speech corector • speech therapy • rehab holidays 


\section{Wstęp}

Jąkanie było już w czasach Hipokratesa przedmiotem zainteresowania terapeutów. Mimo iż upłynęło tyle lat, stanowi wyzwanie dla współczesnej medycyny i przedstawicieli innych specjalności zajmujących się jąkaniem.

Szacuje się, że zaburzenie to występuje u $1 \%$ populacji na świecie. Przyjmuje się, że problem jąkania dotyczy około pół miliona Polaków. Różnorodność czynników etiologicznych czyni procedurę diagnostyczną trudną, zaś efekty terapii niedoskonałymi. Problematyka jąkania stanowi wyzwanie dla lekarzy i naukowców w poszukiwaniu coraz to nowych elementów terapeutycznych, które mogą poprawić skuteczność prowadzonej rehabilitacji osób jąkających się.

Omawiane w literaturze przedmiotu konceptualne teorie dotyczące przyczyn jąkania nie wyjaśniają do końca mechanizmów powstania tego zaburzenia, istnieje zatem konieczność wypracowania skutecznej strategii diagnostyczno-terapeutycznej warunkującej sukces.

Istotne jest więc zaplanowanie i zorganizowanie procesu terapeutycznego tak, aby odbywał się kompleksowo i w sposób zorganizowany, wykorzystując interdyscyplinarne podejście mające na celu jak najbardziej skuteczną pomoc osobom jąkającym się.

Jąkanie jest specyficznym zaburzeniem komunikacji interpersonalnej o charakterze mimowolnym, ograniczającym w znacznym stopniu spontaniczność mówienia [Tarkowski, 2007].

Jąkanie jest wynikiem dyskoordynacji ruchowej aparatów: oddechowego, fonacyjnego i artykulacyjnego, charakteryzującym się brakiem płynności mówienia w procesie komunikacji między nadawcą (osobą jąkającą się) i odbiorcą wypowiedzi [Chęciek, 2007].

Problemy mogą występować na początku lub w trakcie mówienia.

W mowie osób jąkających się dochodzi do powtarzania pojedynczych głosek, sylab, słów, części zdań, rewizji wypowiedzi, jak również przeciągania głosek, blokowania, pojawiają się pauzy, nadmiernie szybkie tempo mowy, unikanie trudnych słów i zastępowanie ich innymi, łatwiejszymi. Jąkaniu mogą towarzyszyć objawy neurowegetatywne w postaci ruchów głową, drgania części twarzy, drżenia głosu, czerwienienia się, pocenia, ruchów kończyn lub całego tułowia, przyspieszonego bicia serca. Mogą współistnieć w jąkaniu stany logofobiczne polegające na wycofywaniu się z pełnienia różnych ról społecznych i sytuacji zadaniowych. Zaburzenie płynności mowy nie zawsze występuje w jednakowym nasileniu. Bywają okresy, kiedy osoba jąkająca się mówi zupełnie płynnie lub okresy wzmożonego nasilenia jąkania będące wynikiem złego samopoczucia, zbyt dużego zaangażowania emocjonalnego, obecności innych czynników stresogennych.

Jąkanie najczęściej występuje na pierwszej sylabie słowa, na pierwszym słowie, na pierwszym zdaniu, na sylabach akcentowanych, częściej na znaczących słowach (rzeczowniki, czasowniki) niż funkcyjnych, na słowach rzadziej używanych, na słowach dłuższych.
Tradycyjne programy terapii polegają na „modyfikacji jąkania”, która ma na celu zmniejszyć niepokój pacjenta i strach przed mówieniem lub na "kształtowaniu płynności", która polega na ćwiczeniu płynnego mówienia [Jones, Onslow, Harrison, Packman, 2000, Waszczuk 2005].

Istnieją próby farmakologicznego leczenia jąkania za pomocą leków obniżających poziom dopaminy w mózgu. Jednak ze względu na działania niepożądane tych leków ten sposób leczenia nie jest powszechnie stosowany. Terapia osób jąkających się powinna uwzględniać indywidualne potrzeby i predyspozycje każdego pacjenta, ale już wiadomo, że musi mieć charakter wielokierunkowy.

Problematyka osób jąkających się od lat zajmuje specjalistów z wielu różnych dziedzin, m.in. lekarzy, logopedów, psychologów, pedagogów i socjologów. Brak bądź utrata tak cennej wartości, jaką jest swobodne komunikowanie się, niesie ze sobą silne przeżycia emocjonalne i często zmusza pacjenta do podporządkowywania i przebudowywania swojego życia.

Mowa i swobodne komunikowanie się to bardzo ważne i pożądane komponenty w życiu człowieka, których brak prowadzi do zmian w funkcjonowaniu psychicznym osób jąkających się. Wymusza to zmianę obrazu samego siebie - wpisanie weń obniżonych możliwości w zakresie płynnego porozumiewania się oraz wymusza rezygnację z niektórych form pracy zawodowej, wymagającej dużej aktywności komunikacyjnej.

Długotrwale występujące jąkanie często powoduje zmiany w psychice osób jąkających się związane z lękiem, napięciem z powodu braku płynnego mówienia, a tym samym generuje problemy emocjonalne i w efekcie może prowadzić do ryzyka powstawania nerwic i depresji.

Osoby jąkające się podzielają opinię, w której jąkanie porównuje się do góry lodowej, gdzie tylko jej wierzchołek wystaje ponad powierzchnię wody, a ogromna reszta kryje się pod powierzchnią. To właśnie te niewidoczne elementy będące ważną składową jąkania powodują u osoby jąkającej się takie stany emocjonalne, jak: złość, smutek, zmieszanie, wstyd, zażenowanie, utrate pewności siebie i wiary we własne możliwości. Strach przed mówieniem i reakcją otoczenia powoduje, że jąkający się nie chce rozmawiać o swoich problemach, a osoba słuchajaca nie porusza tego tematu sądząc, że może urazić osobę jąkającą się. Jąkanie jest specyficznym zaburzeniem występującym we wszystkich rasach, kulturach i językach. Nie każda osoba, która mówi niepłynnie czuje się osobą jąkającą się. Można więc wyciągnąć wniosek, że osobą jąkającą się jest ta, która taką się czuje.

Program opieki nad pacjentami jąkającymi się zapoczątkowany w Instytucie Fizjologii i Patologii Słuchu w 1998 roku, oparty na wykorzystaniu cyfrowego korektora mowy i terapii logopedycznej, pozwolił osobom jąkającym się na powrót do lepszego funkcjonowania komunikacyjno-społecznego. Prowadzone działania miały na celu wypracowanie interdyscyplinarnego modelu postępowania diagnostyczno-rehabilitacyjnego, który ułatwi osobom jąkającym się wdrożenie i wykorzystanie dostępnych metod wspomagających przy jąkaniu w codziennych sytuacjach komunikacyjnych. 
Cel

Głównym celem niniejszej pracy jest przedstawienie schematu postępowania $\mathrm{z}$ osobami jąkającymi się $\mathrm{w}$ aspekcie terapii logopedycznej, a także prezentacja wyników badań dotycząca efektów stosowania programu terapeutyczno-rehabilitacyjnego z zastosowaniem cyfrowego korektora mowy.

\section{Materiał i metoda}

W chwili obecnej pod opieką IFPS znajduje się około 3500 pacjentów z zaburzeniami mowy i komunikacji. Przeprowadzone działania diagnostyczne, pozwoliły na wyłonienie grupy 335 pacjentów, którzy zostali skierowani na turnusy terapeutyczne dla osób jąkających się, oparte na intensywnej terapii logopedycznej z wykorzystaniem cyfrowego korektora mowy

Materiał stanowiła w/w grupa osób jąkających się, w wieku od 6 do 64 lat, którzy spełniali przyjęte kryteria kwalifikacji. Były to osoby jąkające się prezentujące jąkanie kloniczne, toniczne i mieszane (kloniczno-toniczne bądź toniczno-kloniczne), bez poprawy płynności mowy przy dotychczas zastosowanych metodach rehabilitacyjnych oraz osoby jąkające się, dotychczas mało intensywnie bądź w ogóle nie rehabilitowane.

W wyłonionej grupie było 268 mężczyzn (80\%) oraz 67 kobiet (20\%). Wybrana grupa pacjentów prezentowała różne typy niepłynności: 196 (58,5\%) - toniczno-kloniczne, 75 $(22,4 \%)$ - toniczne, $63(18,9 \%)$ - kloniczne, 1 (0,2\%) - giełkot.

Ocenę efektywności prowadzonej terapii wyznaczono na podstawie wyników Próby Sylabowej do Oceny Niepłynności Mówienia według Kurkowskiego oraz w oparciu o ankietę uwzględniającą poziom satysfakcji pacjenta $\mathrm{z}$ wykorzystanie cyfrowego korektora mowy w trakcie trwania turnusu. Niepłynność mówienia przy zastosowaniu próby sylabowej była oceniana ilościowo w postaci wyniku procentowego przy: czytaniu, swobodnej rozmowie oraz przy opowiadaniu historyjki obrazkowej. Badanie przeprowadzono dwukrotnie: przed rozpoczęciem terapii i po jej zakończeniu. Pytania ankietowe dotyczące poziomu satysfakcji pacjenta $\mathrm{z}$ wykorzystania cyfrowego korektora mowy były ocenianie w oparciu o czterostopniową skalę: bardzo duża, duża, umiarkowana, bardzo mała lub jej brak.

\section{Turnusy rehabilitacyjne}

Turnusy organizowane przez IFPS, w formie ukierunkowanej terapii nastawione są na uzyskania trwałych efektów w postaci poprawy płynności mowy.

Terapia, prowadzona w trakcie tygodniowych pobytów wyjazdowych, odbywa się $\mathrm{w}$ formie pracy grupowej (510 osób) oraz indywidualnej i dostosowana jest do możliwości wiekowych, uwzględniając potrzeby pacjentów wynikające ze wstępnej diagnozy.

Czas zajęć to minimum 5 godzin dziennie. Nie wprowadza się ścisłych ograniczeń czasowych terapii. Zajęcia prowadzone są w blokach porannych i popołudniowych, by nie doprowadzić do zmęczenia i dyskomfortu uczestników.
Podstawowym założeniem pracy logopedycznej podczas turnusów jest wypracowanie następujących celów: swobodna komunikacja i wyrażanie myśli bez narażania się na krytykę i śmieszność, odważniejsze podejmowanie zachowań komunikacyjnych, wzrost poczucia własnej wartości i pewności siebie, zmniejszenia napięcia mięśniowego, osiągnięcie stanu relaksu, wyciszenia, stabilizacji emocjonalnej oraz nauka praktycznego wykorzystania wiedzy i umiejętności zdobytych w trakcie zajęć w mowie zautomatyzowanej podczas codziennej komunikacji.

Pracę terapeutyczną podczas turnusu rozpoczyna spotkanie ze wszystkimi uczestnikami, podczas którego omawiana jest sama problematyka jąkania oraz realne wskaźniki efektywności i zakresu odpowiedzialności każdej ze stron uczestniczących w terapii.

Dla uzyskanie lepszych efektów prowadzonych działań terapeutycznych istotne jest uświadomienie uczestnikom oraz opiekunom zasad systematyczności pracy zgodnie z przekazanymi wskazaniami. Demonstracja i korygowanie na bieżąco nieprawidłowo wykonywanych zadań logopedycznych oraz komentarz podczas prowadzonych zajęć pozwalają uzyskać lepsze rezultaty w pracy nad płynną mową.

Płynność mowy można uzyskać stosując odpowiednie techniki i zasady terapeutyczne, $\mathrm{z}$ którymi pacjenci zapoznają się w trakcie zajęć turnusowych.

Prowadzona terapia obejmuje: ćwiczenia z zakresu fizjoterapii oddechowej, ćwiczenia regulacji napięcia mięśniowego w obrębie obwodowego narządu mowy oraz całego ciała, ćwiczenia startu mowy i rytmizacji wypowiedzi, ćwiczenia relaksacyjne oraz ćwiczenia z wykorzystaniem cyfrowego korektora mowy (CKM) (Rycina 1).

Zajęcia indywidualne pozwoliły na zmierzenie się z najbardziej dotkliwymi symptomami jąkania oraz indywidualnymi strategiami kamuflażu i pomoc pacjentowi w przezwyciężeniu trudności na rzecz swobody komunikacyjnej w kontaktach interpersonalnych.

Zajęcia grupowe mają natomiast istotne znaczenie w procesie terapeutycznym zwłaszcza dla osób, u których występują stany logofobiczne. Członkowie grupy motywowali się wzajemnie do pracy, udzielali sobie wsparcia emocjonalnego do walki z jąkaniem oraz dzielili własnymi doświadczeniami i odczuciami w zakresie radzenia sobie $\mathrm{z}$ jąkaniem w różnych sytuacjach życiowych. Często dla samych osób jąkających się stanowiło to bardzo ważny czynnik decydujący o pełniejszym zaangażowaniu się w proces terapeutyczny, kształtowaniu odpowiedniego nastawienia do radzenia sobie $\mathrm{z}$ emocjami w sytuacjach stresujących.

\section{Cyfrowy Korektor Mowy}

Wykorzystywany od 1998 roku w IIFPS Cyfrowy Korektor Mowy (CKM) w terapii osób jąkających się jest nowatorskim urządzeniem skonstruowanym we współpracy między Politechniką Gdańską i Dalhousie University (Kanada). Zastosowano w nim możliwość wykorzystania dwóch opcji terapeutycznych: DAF (Delayed Auditory Feedback) oraz FAF (Frequency - shifted Auditory Feedback). 


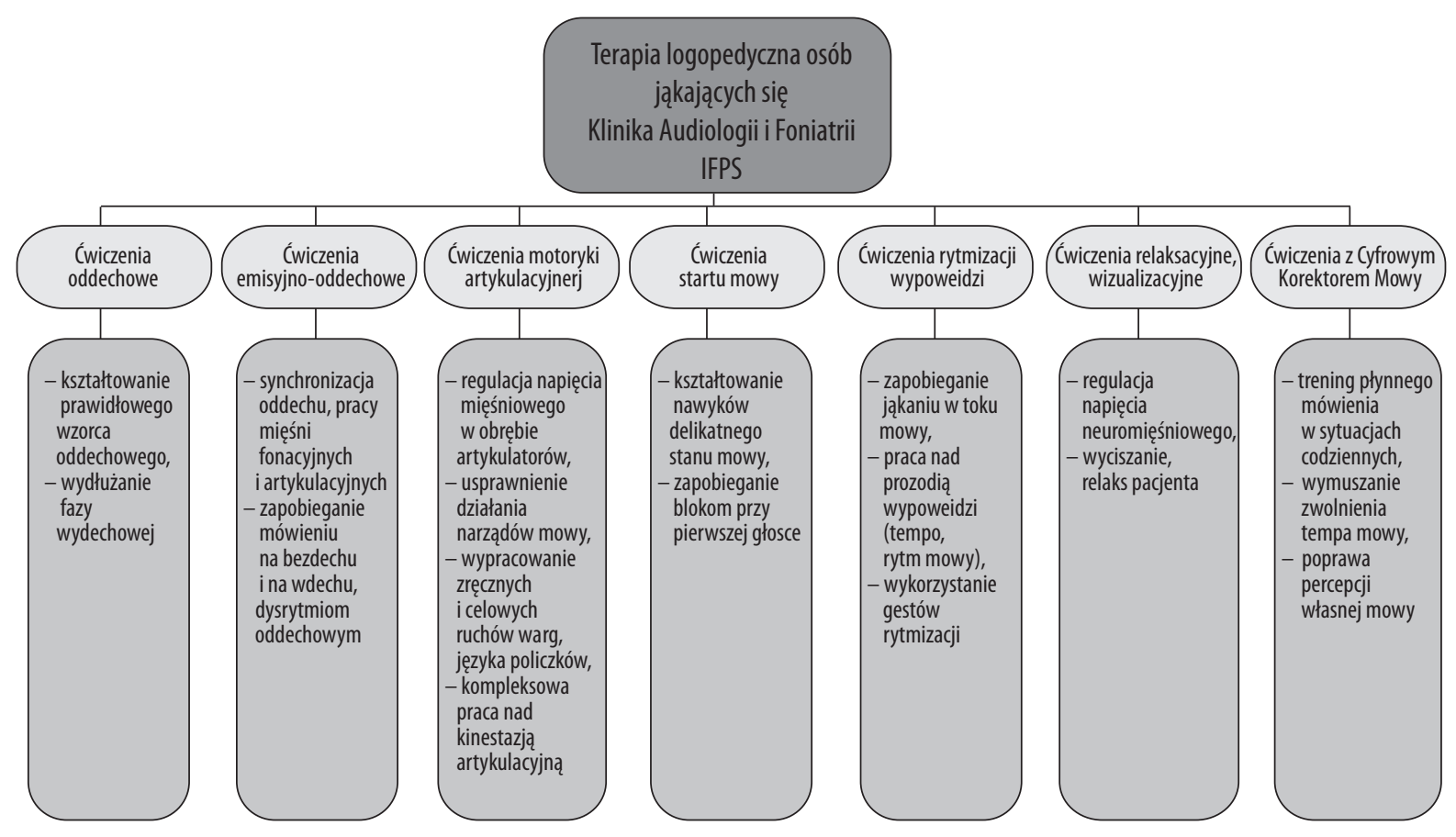

Rycina 1. Schemat terapii logopedycznej osób jąkających się

Urządzenie w postaci cyfrowego korektora mowy (CKM) daje możliwość zastosowania wielu kombinacji ustawień i dobierania różnych wartości opóźnienia czasowego (od 0 do $300 \mathrm{~ms}$ ) i transpozycji częstotliwości (od 0 do 4/5 oktawy). Wykorzystywany w trakcie terapii schemat ustawień CKM jest dobierany indywidualnie dla każdego pacjenta, podczas pobytu diagnostycznego w IFiPS. Możliwe do wykorzystanie kombinacje ustawień to DAF, FAF lub DAF+FAF

DAF sprawia, że pacjent słyszy własny głos z opóźnieniem ułamka sekund. Słyszenie swojego głosu z opóźnieniem sprawia, że jąkający się mówi wolniej, co polepsza płynność mowy. Zastosowanie DAF nie wymaga żadnego specjalnego treningu i jest efektywne zarówno u dzieci, jak i u dorosłych.

Natomiast podczas wykorzystywania FAF pacjent słyszy swój głos podwyższony lub obniżony o około pół oktawy.

Wadą korekcji jąkania z wykorzystaniem CKM w opcji DAF (opóźnienie słyszenia własnego głosu) jest fakt, że mowa staje się powolna i monotonna, co często bywa powodem odrzucenia tego urządzenia przez pacjentów w procesie rehabilitacji. Kalinowski (1993) podaje 55\% skuteczności przy wykorzystaniu powyższej metody, Brenaut (1995) 71\%.

Przy połączeniu i zastosowaniu obu możliwości (DAF i FAF) Kehoe (1998) uzyskał u swoich pacjentów 70-85\% skuteczności, zaś po zastosowaniu jednocześnie rehabilitacji logopedycznej otrzymano $100 \%$ poprawy płynności mowy [Kehoe, 1997].

Wyniki badań własnych przeprowadzonych w IFiPS (2003) wykazały 96\% skuteczności w zakresie poprawy płynności mowy i są zbliżone do wyników uzyskanych przez innych autorów a tym samym potwierdzają dobrą skuteczność zastosowanego programu rehabilitacyjnego z wykorzystaniem wielu elementów terapeutycznych [Szkiełkowska i wsp., 2003].

Po zakończonej terapii przeprowadzono również badanie mające na celu subiektywną ocenę korzyści z cyfrowego korektora mowy dokonaną przez samych pacjentów w proponowanej skali: bardzo duża, duża, umiarkowana, mała lub jej brak.

Obecnie w IFiPS wykorzystywane są w terapii dwa urządzenia. Jedno jest pudełkowe, jego wielkość pozwala zmieścić urządzenie w kieszeni. Natomiast druga wersja to urządzenie wewnątrzuszne - subminiaturowy korektor mowy, z którego można korzystać po wykonaniu indywidualnej wkładki wewnątrzusznej. Dzięki znacznemu zminiaturyzowaniu jest prawie niewidoczne dla osoby postronnej, co nie pozostaje bez znaczenia w przypadku młodzieży i dorosłych starających się o dużą dyskrecję w zakresie informowania otoczenia o swoim problemie, jakim jest jąkanie.

Sukcesywne ćwiczenia z CKM i doświadczanie coraz płynniejszej mowy w miarę korzystania $\mathrm{z}$ urządzenia zwiększały motywację do pracy własnej.

Urządzenie o niewielkich rozmiarach daje pacjentowi możliwość korzystania w różnych codziennych sytuacjach komunikacyjnych, z którymi często sobie nie radzi, które wydają się dla niego za trudne (Rycina 2).

Dzięki systematycznej pracy samego pacjenta podczas zajęć indywidualnych i grupowych oraz kontynuowania zadań logopedycznych w czasie wolnym możliwe było uzyskanie dobrych efektów terapeutycznych w postaci poprawy płynności mowy. 

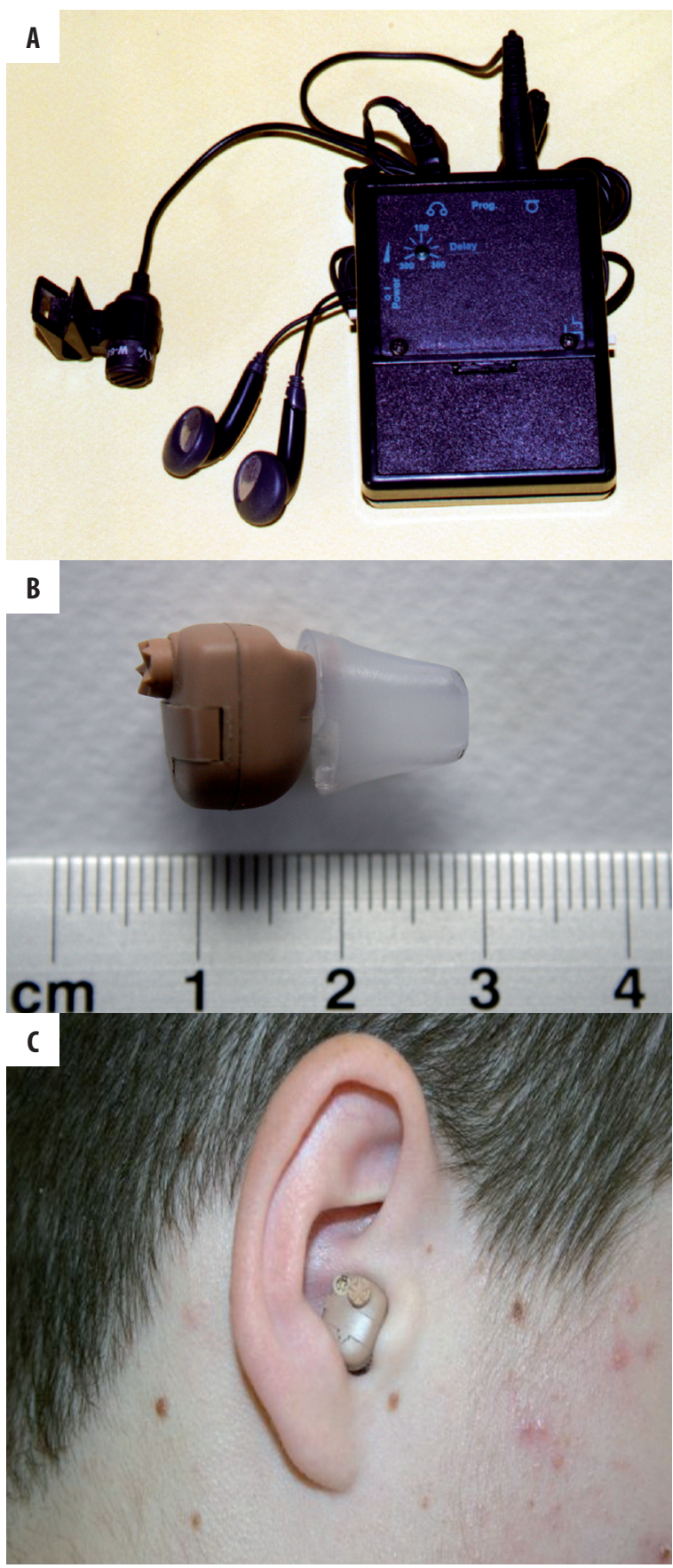

Rycina 2A-C. Cyfrowe korektory mowy

Należy zwrócić uwagę, że w pracy z osobami jąkającymi się ważne jest zarówno doświadczenie zawodowe, jak i osobowość terapeuty, który poza działaniami rehabilitacyjnymi udziela wsparcia i pomocy. Skuteczny terapeuta zachęca, pokazuje, motywuje i asertywnie wspiera, wymagając od pacjenta zaangażowania i pracy własnej na rzecz płynnego mówienia. Swoją postawą życzliwej akceptacji i wiary w skuteczność podejmowanych działań rehabilitacyjnych pokazuje, że osoby jąkające się nie są osamotnione $w$ walce $z$ jąkaniem. Przyjazna atmosfera pracy oraz pomoc i wsparcie psychiczne wpływają korzystnie na otwarcie emocjonalne i komunikacyjne, a tym samym satysfakcję pacjenta w zakresie uzyskiwanej poprawy płynnego mówienia.

\section{Wyniki}

Po zakończeniu terapii dokonano ewaluacji stanu płynności mowy.

Ocena końcowa efektów terapii na podstawie Próby Sylabowej do Oceny Niepłynności Mówienia według Kurkowskiego, wykazała zmiany ilościowe w każdej z badanych kategorii. Największy procent poprawy uzyskano w zakresie czytania tekstu. U 96\% badanych pacjentów nastąpił wzrost płynności mowy. Nieco niższy wynik uzyskano w kategorii opowiadanie historyjki obrazkowej. Odnotowano poprawę płynności mowy u $92 \%$ badanych osób. Stosunkowo najmniejszą wartość poprawy płynności mowy odnotowano w kategorii dialog. Uzyskało ją 90\% badanych osób.

W grupie badanych osób z wykorzystujących podczas terapii CKM, w postaci DAF korzystało $12 \%$ pacjentów, FAF wprowadzono dla $9 \%$ pacjentów, natomiast opcja DAF+FAF było preferowane przez $79 \%$ pacjentów. Subiektywna ocena korzyści z korektora dokonana przez pacjentów, po zakończonej terapii oceniana była oceniana w skali jako: bardzo duża - 13\% pacjentów, duża - 53\% pacjentów, umiarkowana - 19\% pacjentów, bardzo mała lub brak $15 \%$ pacjentów

Cyfrowy korektor mowy wykorzystujący opóźnienie czasowe i transpozycję częstotliwościową własnego głosu był dobrze tolerowany i pozytywnie oceniany przez większość jąkających się pacjentów.

Na podstawie próby sylabowej stwierdzono, że średnio 92\% pacjentów, którzy korzystali $\mathrm{z}$ takiej formy terapii uzyskało obiektywną poprawę w zakresie płynności mowy.

\section{Podsumowanie}

Wykorzystując obecny stan wiedzy z obszaru terapeutyczno-rehabilitacyjnego w odniesieniu do osób jąkających się stwierdza się, że możliwe jest uzyskanie w trakcie pracy terapeutycznej dobrych rezultatów w zakresie poprawy płynności mowy. Wysiłki terapeutów idą w kierunku poszukiwania i wykorzystania optymalnego zestawu metod, które pozwalają najskuteczniej i najefektywniej wspomóc pacjentów jąkających się. Obserwacje własne potwierdziły, że wprowadzenie wieloprofilowej terapii u osób jąkających się może poprawić w znacznym stopniu ostateczne efekty rehabilitacji u tych pacjentów.

W efekcie prowadzonych kompleksowo działań nad poprawą płynności mowy dąży się do uzyskania gotowości wykorzystania technik usprawniających płynność mowy w toku codziennej komunikacji. Dzięki zastosowaniu różnorodnych metod w pracy terapeutycznej osiąga się zwiększenie otwartości i gotowości do podejmowania nowych wyzwań komunikacyjnych oraz obniżenie stresu komunikacyjnego, co wpływa na poprawę samooceny oraz większą satysfakcje i swobodę w zakresie kontaktów werbalnych.

Znaczna część osób jąkających się odczuwa skrępowanie i zawstydzenie swoją wadą wymowy; czują się wyobcowani, boją się odezwać, by nie stać się obiektem żartów i docinków. Natomiast ludzie mówiący płynnie odczuwają zażenowanie, gdy ktoś rozmawiający z nimi jąka 
się. Nie wiedzą, jak zachować się w takiej sytuacji; nawet, gdy chcą pomóc, nie wiedzą jak. Najczęstszym rozwiązaniem tej kłopotliwej - dla obydwu stron - sytuacji jest ucieczka od problemu (nieodzywanie się, niesłuchanie, próby kończenia wypowiedzi za osobę jąkająca się). Tym samym powstaje błędne koło, skutkujące izolacją społeczną osób jąkających się. Dlatego tak ważna dla pacjenta jest możliwość korzystania $\mathrm{z}$ urządzenia o minimalnych rozmiarach, którego dyskretność w ocenie pacjenta jest niezwykle ważna.

Prowadzona w IFiPS strategia postępowania w zakresie rehabilitacji pacjentów jąkających się z wykorzystaniem terapii logopedycznej i cyfrowego korektora mowy może stanowić skuteczną pomoc dla osób jąkających się. Zarówno wyniki badania, jak i obserwacje autorów pracy potwierdzają pogląd, że systematyczny trening mówienia wsparty wykorzystaniem cyfrowego korektora mowy daje pacjentom możliwość uzyskania poprawy płynności mowy.
„Dopóki walczysz, jesteś zwycięzcą” - św. Augustyn (Aureliusz Augustyn z Hippony).

\section{Wnioski}

1. Terapia logopedyczna jest nieodzownym elementem interdyscyplinarnej opieki nad osobami jąkającymi się.

2. Forma terapeutyczna w postaci turnusów $\mathrm{z}$ intensywną rehabilitacją logopedyczną i wykorzystaniem w trakcie jej trwania cyfrowego korektora mowy (CKM) pozwala uzyskać pożądane rezultaty w postaci bardziej płynnej mowy oraz stanowi atrakcyjną i efektywną metodę w terapii osób jąkających się.

3. Wprowadzenie osoby jąkającej się w płynny akt komunikacyjny wymaga podkreślenia roli pracy własnej samego zainteresowanego na rzecz płynnego mówienia.

4. Cyfrowy korektor mowy jest cennym elementem wspomagającym rehabilitację osób z zaburzeniami płynności mowy

\section{Piśmiennictwo:}

1. Adamczyk B.: Terapia jąkania metodą ECHO. (W:) Diagnoza i terapia zaburzeń mowy. Wydawnictwo Uniwersytetu Marii Curie-Skłodowskiej, Lublin, 1993; 141-55

2. Chęciek M.: Jąkanie. Diagnoza - terapia - program. Oficyna Wydawnicza Impuls, Kraków, 2007

3. Jones M., OnslowM., HarrisonE., Packman A.: Treaning stuttering in Young choldren: Predicting Treatment time inthe Lidcombe Program. J Speech Hear Res, 2000, 43(6) 1440-50

4. Kalinowski J., Armson J., Stuart A., Graco V.: Effect ofalterantions in auditory feedback and speech rate on stattering frequensy. Language and Speech, 1993; 36: 1-16

5. Kamińska D.: Wspomaganie płynności mowy dziecka - profilaktyka, diagnoza i terapia jąkania wczesnodziecięcego. Oficyna Wydawnicza Impuls, Kraków, 2006

6. Kehoe T.D.: Stutterin: Science, Therapy and Practice. Casa Futura Technologies, 1997

7. Kurkowski Z.M.: Próba sylabowa do oceny niepłynności mówienia Instytut Fizjologii i Patologii Słuchu, Warszawa, 2003
8. Onslow M., Costa L., Andrews C.: Speech outcomes of a prolonged- speech treatment for stuttering. J. Speech Hear Res, 1996; 39(4): 734-49

9. Ratyńska J., Szkiełkowska A, Markowska R. i wsp.: Immediate speech fluency improvement after application of the Digital Speech Aid in stuttering patients. Med Sci Monit, 2012; 18(1): CR9-12

10. Ratyńska J., Szkiełkowska A., Markowska R., i wsp.: Stuttering patients' opinions on the Digital Speech Aid. Med Sci Monit, 2009; 15(7): CR355-60

11. Szkiełkowska A., Ratyńska J., Czyżewski A., i wsp.: Schemat postępowania terapeutyczno-rehabilitacyjnego u osób jąkających się. Otolaryngologia Polska, 2003; LVII(4): 555-59

12. Tarkowski Z.: Psychosomatyka jąkania. Dlaczego osoby jąkające się mówią płynnie? Wydawnictwo Fundacji Orator, Lublin, 2007

13. Waszczuk H.: Rodzinna terapia jąkania - poradnik. Fundacja Rozwoju Uniwersytetu Gdańskiego, Sopot, 2005 